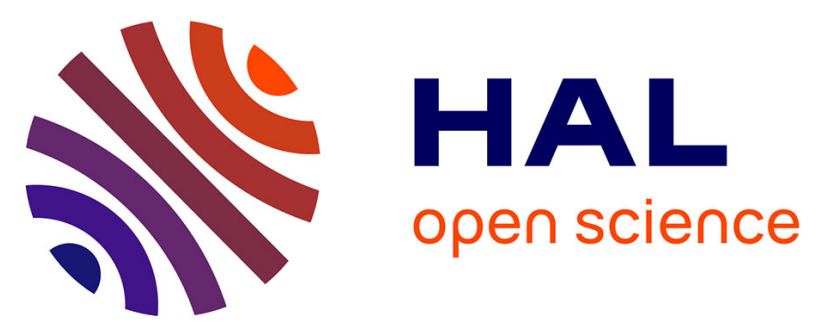

\title{
Management practices to minimize land use conflicts on large infrastructure projects: examples of dams construction in Pakistan
}

\author{
Habibullah Magsi, Muazzam Sabir, André Torre, Abbas Ali Chandio
}

\section{To cite this version:}

Habibullah Magsi, Muazzam Sabir, André Torre, Abbas Ali Chandio. Management practices to minimize land use conflicts on large infrastructure projects: examples of dams construction in Pakistan. GeoJournal, 2021, 10.1007/s10708-021-10532-0 . hal-03439355

\section{HAL Id: hal-03439355 \\ https://hal.inrae.fr/hal-03439355}

Submitted on 30 Nov 2021

HAL is a multi-disciplinary open access archive for the deposit and dissemination of scientific research documents, whether they are published or not. The documents may come from teaching and research institutions in France or abroad, or from public or private research centers.
L'archive ouverte pluridisciplinaire HAL, est destinée au dépôt et à la diffusion de documents scientifiques de niveau recherche, publiés ou non, émanant des établissements d'enseignement et de recherche français ou étrangers, des laboratoires publics ou privés.

\section{(1) (1) $\$$}

Distributed under a Creative Commons Attribution - NonCommercial - NoDerivatives $\mid 4.0$ 


\title{
Management practices to minimize land use conflicts on large infrastructure projects: examples of dams construction in Pakistan
}

\author{
Habibullah Magsi* \\ Department of Agri. Economics, Sindh Agriculture University Tandojam, Pakistan. \\ Email: hmagsi@sau.edu.pk \\ Muazzam Sabir \\ Department of Agri. Economics, University of Sargodha, Pakistan \\ Email: muazzam.sabir@uos.edu.pk \\ Andre Torre \\ INRAE AgroParisTech, University Paris-Saclay, France \\ Email: andre.torre@wanadoo.fr \\ Abbas Ali Chandio \\ College of Economics, Sichuan Agricultural University, Chengdu, China. \\ Email: alichandio@sicau.edu.cn \\ *Corresponding authors: \\ E-mail: alichandio@sicau.edu.cn (A.A. Chandio); hmagsi@sau.edu.pk (H.Magsi)
}

\begin{abstract}
In this research two cases of infrastructure development (Chotiari and Diamer Bhasha Dams) from Pakistan were studied in terms of a superposition of land use expectations and their consequences. For this purpose, we obtained qualitative information from both primary as well as secondary sources. Primary data were collected through a partially developed questionnaire from pre-selected experts of various professional backgrounds. National and regional dailies along with other published literature were used as a secondary source of information. The findings have identified the key groups of stakeholders and their relative social power at different levels of governance. The results further highlight that unfair land acquisition, improper displacement, mismanagement in compensation, etc., have caused negative impacts on local people and the surrounded environment. The article further emphasizes governance issues and conflicts among different actors due to the project. Finally, we recommend several actions to prevent strong oppositions and conflicts in the infrastructural project in developing countries, like the enhancement of the capacities and the capabilities of the local population, the diffusion of information and the involvement of stakeholders, and the application of technical tools and devices.
\end{abstract}

Keywords: Infrastructure; Conflict; Proximity relations; Superposition; Pakistan JEL Classification: D74, H54, O16

\section{Introduction}

Superposition of land use expectations and competition over land uses for different projects have produced conflicts, mainly due to ignorance of rights (physical or social), forceful displacement, and delayed justice (Wehrmann, 2008; Torre et al., 2014; Magsi et al., 2017). In fact, the larg development projects especially the dams are directly proportionate to the increase in the 
population (demand); but, mainly affected agricultural lands (Ha et al., 2016), natural resources (Ostrom and Nagendra, 2006), which has created frustrations in rural masses (Nüsser 2003). Such oppositions encouraged them to unite and protest for their rights, by means of voice attitudes (in the sense of Hirschman, 1970), protestations, recourse to the tribunals, or violent oppositions.

Theoretically, the land use conflicts are the result of a lack of social justice and recognized rights in rural areas (Ostrom, 1990), such conflicts are sparked more when owners are forcibly dispossessed from natural resources, i.e., land, water, or forests (Tilt et al. 2009; Ostrom and Nagendra, 2006). According to the welfare economic aspects of land use conflicts (social welfare theory), the superposition of lands must not depend on from one use to another use, on its efficient distribution with respect to the economic activities (Cheshire and Vermeulen, 2009).

For assured agriculture in developing countries like Pakistan, there is a need to store water; but, if the big projects like dams are based on faulty planning, they might generate social and environmental disputes (Baghel and Nüsser, 2010). Pakistan is an agricultural country, meanwhile, it is also classified as a water scarce country, where water availability is less than 1000 cubic meters per person per year. In addition to water scarcity, the electricity shortage urged the authorities to focus on dam and reservoir projects (GoP, 2020). A lot of people are being affected socioeconomically by the land acquisition process related to these projects, although the importance of these dams and reservoirs cannot be ignored. The government claimed that such projects in the past raised the living standard of the people by providing employment opportunities and development of the affected area, but in fact, most of them led to low living standards, poverty, and social instability (Magsi and Torre, 2014). This raises a serious question over Pakistani authorities for construction of Bhasha Dam, the land acquisition of which is almost completed and there exists a lot of conflicts among stakeholders, badly affecting local people like projects in past (Sabir et al., 2017).

This study tries to give the understanding of factors responsible for the superposition and the competition of land uses for large development projects and the rural livelihood; particularly, it discusses the cases of Chotiari and Bhasha dams from Pakistan. The research is based on descriptive analysis where it points out the factors of significant importance after in depth investigation of flawed projects related to dam and water reservoir construction. Its main purpose is to find out the factors of controversies and to suggest preventive measures for upcoming land use conflicts in the country.

The first part deals with the methodology of this study along with the description of both case studies. The second one emphasizes the stakeholders' involvement, disagreements, and causes of the conflicts related to the superposition of lands for both projects. Then the findings of both cases are provided, including the involvement of the stakeholders and their behaviors as well as the controversies and conflicts created by the projects. Finally, we recommend several actions to prevent strong opposition and conflicts in the infrastructural project in developing countries, like the enhancement of the capacities and the capabilities of the local population, the diffusion of information and the involvement of stakeholders, and the application of technical tools and devices. 


\section{Methodological considerations}

This section gives emphasis to the case studies, sampling procedure, data sources, as well as analytical measures. It also encompasses the methodological options chosen in our research and provides with some core information about the two study zones.

\subsection{Descriptive evidence of the construction projects: Chotiari water reservoir and Diamer Bhasha dam projects}

Two large constructions - Chotiari and Diamer Bhasha Dams - were selected for this research project, because of their specific natures. The Chotiari Dam has already been constructed, where the Diamer Bhasha dam construction has started in the country. The purpose of both case selections is to see the factors which caused conflicts in large construction projects and how such factors are to be managed to minimize the occurrence of future conflicts.

Figure-1: Location of the Bhasha and the Chotiari dams

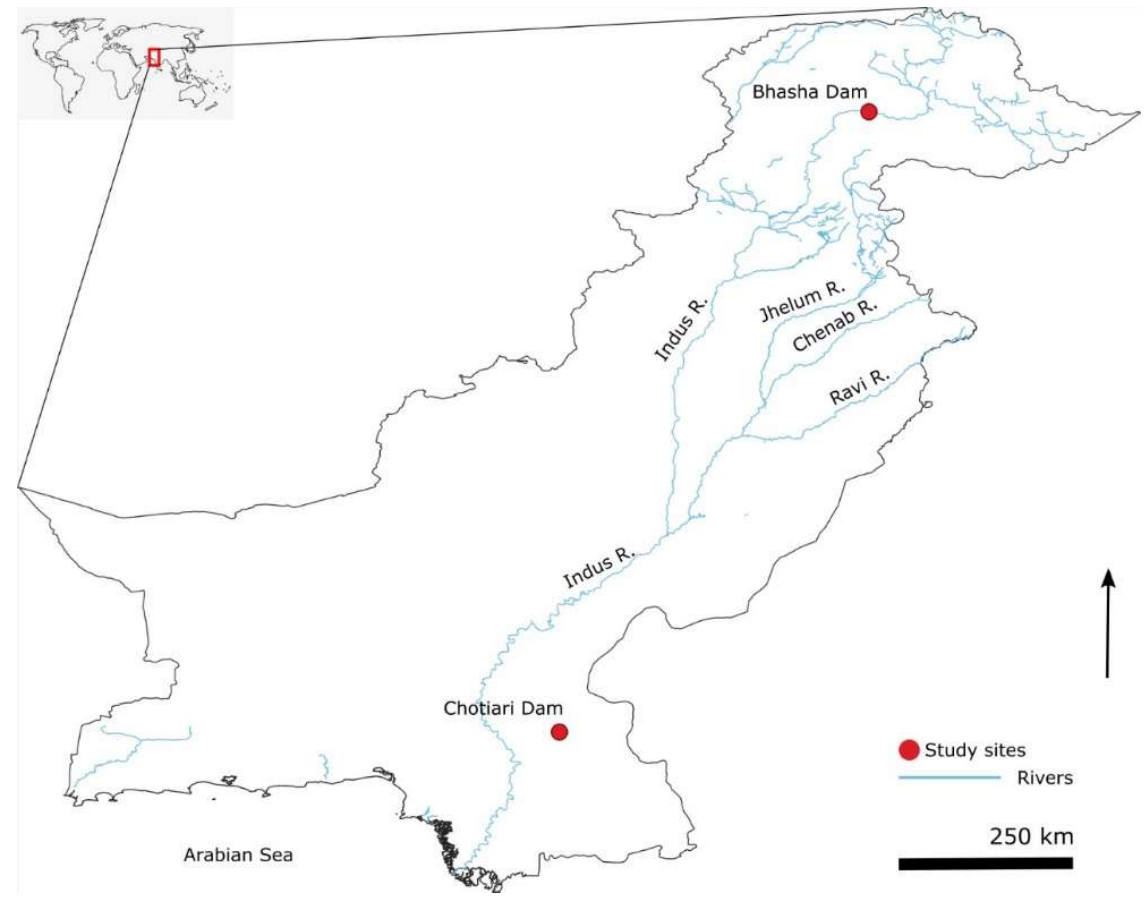

Source: Developed by the authors

\subsubsection{Chotiari Dam}

The Chotiari reservoir project constructed on over 18,000 hectares of land along side the Indus Basin. It was planned to increase the storage capacity of existed lakes in the wetlands of Chotiari, aimed to store monsoon water for agriculture (GoP, 1998). In this way, it could irrigate about 0.12 million hectares of land of three districts including Sanghar, Shaheed Benazirabad, and Mirpur Khas. The reservoir capacity was enhanced to 0.75 Million Acre Feet (MAF) which covers an area of approximately 160 square kilometers. The project cost escalated from the US \$26.3 million 
to the US \$105 million from its planned construction time i.e., 1997 to the actual start of construction i.e., 2002 due to inefficient planning and mismanagement (Iqbal, 2004).

\subsubsection{Diamer Bhasha dam}

Diamer Bhasha dam was planned to overcome the electricity and water shortages in the country. The project was named based on its geographic location which is on the boundary of two provinces "Khyber Pakhtunkhwa" (KPK) and "Gilgit Baltistan" (GB). Diamer is named after a district in GB, while Bhasha is a village in KPK. Water and Power Development Authority (WAPDA) is the main institution in Pakistan responsible for the construction of water reservoirs (with its other objectives). This project was a part of its vision 2025. The feasibility of this project was started in 2001 as a priority (Dawn, 2006). After completion of the Engineering design in 2008, the cost of the project was estimated at the US \$13.684 billion and approved in 2012. Innitially, the World Bank and Asian Development Banks were approached for the funding requirements of this project, but no commitment has been received, either may be due to less interest, or may be due to political controversy between Pakistan and India. The project has completed its land acquisition phase aftermath of China Pakistan Economics Corridor memorandum; therefore, it covers an area of 110 $\mathrm{Km}^{2}$ (GoP, 2013).

\subsection{Data sources and analytical measures}

For data collection, primary and secondary sources of information were selected. As primary source interviews from experts and stakeholders of different backgrounds were carried out. They included administrators (irrigation and water sectors), researchers, private organizations, and legal experts to have their opinion on different issues of the Chotiari and Bhasha dam projects. To cover the conflict information in all dimensions some directly affected households were also interviewed. Finally, fifty interviews from each project area were conducted (see table 1).

The interviews were conducted with partially designed questionnaires, from which some questions were excluded to ask according to experts' professional backgrounds. The main questions included were: (1) situation before conflicts in the area and position of the actors, (2) behavior of different institutions in land acquisition and compensation decision, and (3) the consequences of the projects.

\section{Table 1. Experts interviewed}

\begin{tabular}{|l|c|c|}
\hline \multirow{2}{*}{ Categories } & \multicolumn{2}{|c|}{ Interviewees } \\
\cline { 2 - 3 } & Chotiari & Diamer Bhasha \\
\hline Affected family heads and landlords & 10 & 10 \\
\hline Administration (water and irrigation sector) & 10 & 10 \\
\hline Local Leaders/representatives & 10 & 10 \\
\hline Researchers and legal experts & 10 & 10 \\
\hline NGOs and journalists & 10 & 10 \\
\hline Total & 50 & 50 \\
\hline
\end{tabular}


Data from national and regional dailies and other published literature on the selected projects were included. Different studies used these kinds of secondary sources (see Awakul and Ogunlana, 2002; Mann and Jeanneaux, 2009; Mahato and Ogunlana, 2011; Torre et al., 2014) for the purpose of cross checking the information from various sources and ultimately better analysis (McCarthy et al., 1996; Deininger and Castagnini, 2006). In our cases, different newspapers at the regional and national levels were selected for the purpose of identification of conflicts and better analysis.

These news articles were selected based on different socioeconomic issues and conflicts related to both projects from the period of 1997 to 2016. Regional dailies were collected through personal visits to regional press offices as well as specific news cuttings were collected from local community-based organization's (CBOs) offices. Whereas the national dailies were directly accessed through their websites. Deep analysis of these newspapers has been conducted along with the facts published by private and public organizations. In this way, we hope to have obtained nice information through different sources and avoided too many biases.

\section{Results \& discussion: conflict and governance failures}

In this section, the findings of both cases are provided, which include the involvement of the various stakeholders and the behavior of the local population. The section further highlights the controversies and oppositions created by the projects, where it is also envisaged the management flaws and governance system failures in both cases.

\subsection{The stakeholders}

Both Chotiari and Bhasha dams have displaced the local population at a large scale, while the people reside in rural areas either depending on agriculture or on fishing activities. Since both territories are laying on the Indus basin, so the majority of the people are depending on fishing, followed by grazing, agriculture, etc. (see Table 2). In case of Chotiari, the fishing communities were engaged with the ecology of the lakes, where fishes were trapped outside the dams. This kind of loss for the local fishing community was not satisfactorily estimated or addressed by the authorities.

Table 2. Descriptive statistics of the projects

\begin{tabular}{|l|l|l|l|}
\hline \multicolumn{2}{|l|}{ Damages } & Chotiari Dam & Bhasha Dam \\
\hline \multirow{2}{*}{ Location (province) } & South (Sindh) & $\begin{array}{l}\text { North (Gilgit Baltistan \& } \\
\text { Khyber Pakhtunkhwa) }\end{array}$ \\
\hline \multirow{2}{*}{ Displacement } & Villages & 47 & 32 \\
\cline { 2 - 4 } & Families & 993 & 4228 \\
\cline { 2 - 4 } & $\begin{array}{l}\text { Persons } \\
\text { affected) }\end{array}$ & 8747 & 28650 \\
\hline Main source of livelihood & Fishing & Agriculture/farming \\
\hline Compensation & $\begin{array}{l}\text { Less than market } \\
\text { value }\end{array}$ & $\begin{array}{l}\text { According to market value, } \\
\text { but delay in payments }\end{array}$ \\
\hline $\begin{array}{l}\text { Literacy level of local } \\
\text { population }\end{array}$ & Very low & Very low \\
\hline
\end{tabular}




\begin{tabular}{|l|l|l|}
\hline $\begin{array}{l}\text { Agricultural land submerged } \\
\text { (acres) }\end{array}$ & 11564 & 2660 \\
\hline Submergence of forest/trees & $\begin{array}{l}\text { Makhi forest (16 } \\
\mathrm{km}^{2} \text { ) }\end{array}$ & 50000 \\
\hline $\begin{array}{l}\text { Submergence of Prehistoric } \\
\text { rock carvings (number) }\end{array}$ & -- & 33000 \\
\hline \multicolumn{2}{|c|}{ Projections during feasibility } \\
\hline Electricity generation & -- & $4500 \mathrm{MW}$ \\
\hline Irrigation & $\begin{array}{l}\text { 0.75 MAF (not } \\
\text { achieved so far) }\end{array}$ & $\begin{array}{l}6.4 \text { MAF live storage of } \\
\text { annual surface water }\end{array}$ \\
\hline Employment & $\begin{array}{l}\text { Only during the } \\
\text { construction of the } \\
\text { project. Local people } \\
\text { worked as labor }\end{array}$ & $\begin{array}{l}\text { Specifically to locals and } \\
\text { afterwards in Agriculture, } \\
\text { industry and commercial } \\
\text { sector }\end{array}$ \\
\hline
\end{tabular}

Source: Extrcated from government published reports, and articles from news dailies

The stakeholders keenly involved in both projects were identified and classified according to their stakes, e.g., local actors, personalities, market related agencies, and institutions (see Table 3). The institutions were operating from national to local levels, with different political interests and positions. Particularly, the instigators of the projects like Planning Commission, Ministry of Irrigation, WAPDA, SIDA, and local leaders were in coalition with the single objective, "to construct the reservoir".

Table 3. The stakeholders involved in the projects

\begin{tabular}{|c|c|c|c|}
\hline \multicolumn{2}{|c|}{ Stakeholders } & Chotiari Dam & Bhasha Dam \\
\hline \multicolumn{2}{|c|}{$\begin{array}{l}\text { Principle Actors } \\
\text { (Local population) }\end{array}$} & $\begin{array}{l}\text { - Farmers } \\
\text { - Livestock herders } \\
\text { - Fishermen } \\
\text { - Others (Government servants, } \\
\text { mechanics, plumbers, wood-cutters, } \\
\text { poultry farmers, carpenters) }\end{array}$ & $\begin{array}{l}\text { - Farmers } \\
\text { - Livestock herders } \\
\text { - Social Workers } \\
\text { - Others (Skilled \& unskilled } \\
\text { workers, Government servants, } \\
\text { Private businessmen) }\end{array}$ \\
\hline \multirow{4}{*}{ 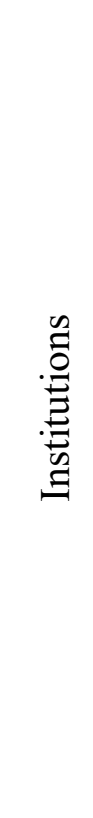 } & National & $\begin{array}{l}\text { - Ministry of Irrigation } \\
\text { - Water \& Power Development } \\
\text { Authority (WAPDA) } \\
\text { - Planning commission of Pakistan - } \\
\text { Pakistan Environmental Protection } \\
\text { Agency }\end{array}$ & $\begin{array}{l}\text { - Planning Commission of } \\
\text { Pakistan } \\
\text { - Water \& Power Development } \\
\text { Authority (WAPDA) }\end{array}$ \\
\hline & Provincial & $\begin{array}{l}\text { - Sindh Environmental Protection } \\
\text { Agency (SEPA) } \\
\text { - Sindh Forest Department (SFD) } \\
\text { - Sindh Irrigation and Drainage } \\
\text { Authority (SIDA) } \\
\text { - Sindh Wildlife Management } \\
\text { Board }\end{array}$ & $\begin{array}{l}\text { - Journalists } \\
\text { - Private consultants for Bhasha } \\
\text { dam \& other related projects }\end{array}$ \\
\hline & Regional & $\begin{array}{l}\text { - World Wildlife Fund (WWF)-City } \\
\text { government }\end{array}$ & - City government \\
\hline & Local & $\begin{array}{l}\text { - District Administration } \\
\text { - Police }\end{array}$ & $\begin{array}{l}\text { - Legal advisors } \\
\text { - Police }\end{array}$ \\
\hline
\end{tabular}




\begin{tabular}{|l|l|l|}
\hline & $\begin{array}{l}\text { - Chotiari Resettlement Agency } \\
\text { (CRA) }\end{array}$ & $\begin{array}{l}\text { - Diamer Poverty Alleviation } \\
\text { Program (NGO) } \\
\text { - District Administration }\end{array}$ \\
\hline $\begin{array}{l}\text { Market related } \\
\text { agencies }\end{array}$ & $\begin{array}{l}\text { - Local Agro-based Industries (fish, } \\
\text { milk, cotton, \& vegetable) }\end{array}$ & \\
\hline $\begin{array}{l}\text { Powerful } \\
\text { personalities } \\
\text { (interested for land } \\
\text { grabbing) }\end{array}$ & $\begin{array}{l}\text { - Local politicians (Locally elected } \\
\text { personalities) }\end{array}$ & $\begin{array}{l}\text { - Local land-lords (Feudal) } \\
\text { - Local land-lords (Feudal) } \\
\text { elected personalities) }\end{array}$ \\
\hline
\end{tabular}

Mostly the different stakeholders, with their different stakes, were involved at different levels. For example, in the Chotiari reservoir situation, it was observed that the relations between stakeholders and local actors were not constructive, as local people (principal actors) were either living in remote areas or scattered in small tribes (GoP, 1998). However, they neither had adequate information about the reservoir construction, nor they were taken on board fully for commencement (Iqbal, 2004). Therefore, the local actors have opposed the reservoir construction decision; contrary, the public authorities (institutions) have seemed in association with local politicians, and the feudal had supported the decision. As a result of that, the implementation of the project became contentious and complicated.

In the case of Bhasha dam, various stakeholders were operating with different stakes, but most of them were interested in the compensation. Several issues were seen among different stakeholders during different project activities. First, land rate compensations were decided after a severe bloody clash between the government and affected people in which three people died (Sabir et al., 2017). However, most of the principal actors stated that this compensation amount was decided under fear to avoid another bloody clash with security forces. Local actors were ignored in decision making in major project activities, along with resettlement and employment decisions which further turned into a source of tensions and conflicts.

\subsection{Controversies and oppositions}

Several development projects have created mistrust and opposition in the developing countries, as most of these projects lack the participation of local affected people in decision making (Magsi et al., 2017). The analysis of both selected case studies through primary and secondary sources brought up the below mentioned root causes of conflicts. Moreover, we also attempted to disclose the disputes among locals and authorities by analyzing the behavior of authorities during different phases of the project implementation. We also put emphasis on the unity of affected people against the project. These issues include corruption events, fewer land compensations, nonpayment of compensations, and the government's decision of compensation payments to selected people. Regarding these issues, the affected people went for violent protests, several times. 
Table 4. Conflicts highlighted by the daily regional press

\begin{tabular}{|c|c|c|}
\hline $\begin{array}{l}\text { Land use conflicts (linked with social, economic and } \\
\text { environment) }\end{array}$ & $\begin{array}{l}\text { Chotiari water } \\
\text { reservoir }\end{array}$ & $\begin{array}{l}\text { Diamer } \\
\text { Bhasha } \\
\text { Dam }\end{array}$ \\
\hline \multicolumn{3}{|l|}{ Land use dimensions } \\
\hline Land acquisition & $\sqrt{ }$ & $\sqrt{ }$ \\
\hline Water logging & $\sqrt{ }$ & - \\
\hline Poor compensation of land values & $\sqrt{ }$ & $\sqrt{ }$ \\
\hline $\begin{array}{l}\text { High cost of resettlement as compared to compensation } \\
\text { amount }\end{array}$ & - & $\sqrt{ }$ \\
\hline Regional boundary issues & - & $\sqrt{ }$ \\
\hline $\begin{array}{l}\text { Land ownership conflict among different groups of local } \\
\text { population }\end{array}$ & - & $\sqrt{ }$ \\
\hline \multicolumn{3}{|l|}{ Social dimensions } \\
\hline Relocation/resettlement & $\sqrt{ }$ & $\sqrt{ }$ \\
\hline Clash between police and local population & $\sqrt{ }$ & $\sqrt{ }$ \\
\hline Fraud property dealing & - & $\sqrt{ }$ \\
\hline Delay in compensation payment & $\sqrt{ }$ & $\sqrt{ }$ \\
\hline $\begin{array}{l}\text { Biasness in employment opportunities \& ineffective } \\
\text { employment plans }\end{array}$ & $\sqrt{ }$ & $\sqrt{ }$ \\
\hline Insufficient public consultation & $\sqrt{ }$ & $\sqrt{ }$ \\
\hline Conflict due to impact on local culture & - & $\sqrt{ }$ \\
\hline \multicolumn{3}{|l|}{ Environmental dimensions } \\
\hline Land degradation due to water logging & $\sqrt{ }$ & $\sqrt{ }$ \\
\hline Stress on flora \& fauna & $\sqrt{ }$ & - \\
\hline Deforestation & $\sqrt{ }$ & $\sqrt{ }$ \\
\hline Damage to prehistoric rock carvings & - & $\sqrt{ }$ \\
\hline
\end{tabular}

Source: Extrcattion from regional dailies

During the Chotiari project, wrongdoings were found in resettlement plans, land acquisition, and the compensation process. The compensation was either below the market values of the resource losses, or it was delayed. The project has also affected the natural resources around. For example, deforestation of Makhi forest and enhancing stress on fauna and flora of the area. Almost half of the land was unentitled while the rest was entitled (private property) thus the question of land compensation from the Government remains unsolved on such lands. This led local people to unite for their causes. No CBOs were present in the area before the start of the project. They arise because of controversies in the project (Abro, 2001), like mismanagement in compensation, relocation as well as in construction funds, environmental problems like water logging, and risk to wildlife in the area.

Like in many rural areas of Pakistan the property is being fragmented from ancestors in the Diamer Bhasha dam locality. Thus, most of the households did not have property papers to avail the compensation of the resource loss as initially announced by the government. The system of land management is in the hands of land administrators called Patwaris ${ }^{1}$, who were authorized by the government to prepare and manage all the land records. Most of the area of Bhasha dam is tribal

\footnotetext{
${ }^{1}$ Local land administrator/government official who keeps the record of land ownerships.
} 
in nature without the existence of the land record and registration of market transactions were unwritten. Based on our interviews with Diamer Bhasha dam affectees, most of the conflicts were linked with wrong measurement, elements of corruption, mismanagement, and cronyism. Corruption and unofficial changes in the land record are common due to the lack of access and reliability of land records of government agents (Patwaris). While taking the advantage of this, a few outside stakeholders have submitted fraudulent property papers for land compensation. Another noticeable conflict between the government and local affected people is related to the category of land to be acquired at some places. To provide compensation, the government has categorized lands as cultivated, cultivable and barren. Local people complained about manipulation of categories by the government from cultivable to barren lands might be done to reduce the amount of compensation.

\subsection{Governance failures}

In big infrastructural projects like dams, the proper information dissemination of all reports at the public level is an important and significant step right from the start of the project to avoid conflicts (Nolte, 2020). In Pakistan, the capability of institutions for planning, implementation, and monitoring to safeguard the public interests is highly questionable (Nauman, 2003). In the Chotiari reservoir case, access to information was not given to local people and their participation was discouraged at most of the stages of the project. On the other hand, the monetary and nonmonetary benefits from the project highlighted the corruption and cronyism of bureaucrats and politicians. Experts in the local area clearly pointed out the failure of bureaucrats and politicians in safeguarding the public interests as they never stood by the side of local people.

In the case of the Diamer Bhasha dam project, poor governance affected the socioeconomics of the local population directly and indirectly. Mismanagement and favoritism were observed in different land acquisition activities, like fewer land measurements, land allotment to favored persons, and manipulation in land categories. Several groups of people were discouraged to participate in the project activities and benefit from the project because of ethnicity. Further, several misconducts from governing bodies put a negative impact on affected people. Some project managers from the government side bought the land in the project area before the start of the construction and then sold it to the government at much higher rates. Many developmental projects including schools, hospitals were approved for the locally affected area but diverted to non-affected areas. Resettlement was delayed due to disputed land for model villages and the construction plan of these villages was not according to local culture. Capacity building programs for employment arranged by Government authorities are poorly interesting for local people due to their lower category job nature, short training period, and less stipend, which local people might not prefer due to cash compensation in hand.

Moreover, besides compensating the local population, the transboundary issue between two provinces, i.e., Gilgit Baltistan and Khyber Pakhtunkhwa, was also highlighted. In fact, before the declaration of the Diamer Bhasha Dam project, the area was under the control of the Gilgit Baltistan government and mostly used as pastures and meadows. After the decision of this project, the territory was claimed by the Khyber Pakhtunkhwa government. However, many experts and stakeholders pointed out that this problem was mainly generated because of the compensation from its seven kilometers long territory and royalty from electricity generation. 
In summary, it is quite reasonable to say that governance failures came to exist, as there was no planning and participation of local people in the land acquisition process, employment and resettlement plans, and compensation decisions or lack of democratic control over the planning and executing agencies of the project.

\section{Land use conflict prevention recommendations for infrastructural projects in developing countries like Pakistan}

The risky and destructive nature of land conflicts needs early prevention solutions, be there in Pakistan or other developing countries. This step of conflicts prevention could prove a valuable tool to limit future tensions and the generation of conflicts that are linked to the opposition of interests of different stakeholders in the use of land. Below mentioned recommendations came from the results obtained from selected case studies, but they can be useful for conflict resolution in the construction of big projects like dams and water reservoirs especially in developing countries like Pakistan.

\subsection{Enhance the capacity and capabilities of the local population}

Our research points some weaknesses in the possibility to react of the local population, due to their lack of knowledge and skills ability. Especially problems related to misinformation or lack of involvement are linked to the low level of education of the local population and their poor knowledge of public and institutional mechanisms. In fact, developing skills among local people is required: they could be helpful to understand the pros and cons of the project, to give their opinion and to negotiate their rights about land and other resources with Government, other public representatives, and big firms. Several agencies might be helpful in this regard including mainly NGOs and donor agencies like Asian Development Bank. Moreover, the involvement of local people in project activities and public debate along with NGOs and media will further help to make the project transparent. It will protect the rights of affected people related to the provision of compensations especially developmental compensations, resettlement, and employment opportunities according to their culture, local traditions, and skills.

Improving the capabilities of local people through education is an important step that gives them more individualistic foundations so as they feel free to choose from a wide variety of different opportunities given to them through their environment and enhance social justice (Sen, 1999). But empowerment approaches are above all, in the sense of improving the competencies and capabilities among affected people to enhance the social linkages and experience-based learning. These training and skill development programs would enable them to take part in project activities, to be informed at every stage, and be active in setting new developmental plans (Scudder, 2005).

\subsection{How to mobilize virtuous of proximities and to avoid negative effects}

We suggest to follow the legal requirements in the sense that all the upcoming proposals of the infrastructural projects and their construction must pass through scrutiny under local context and perspectives by a multidisciplinary team. Following this, an open and unbiased procedure of participation of all stakeholders must be encouraged with the ambition of the development of a particular area based on common ideas and desires. Further, we also recommend bringing in socioeconomic and environmental measures to protect the social policy, to ensure the rights of locals at least at a minimum level according to the mandate of the project, and formulate the main 
parameters for monitoring authorities which were absent in case of Chotiari and Diamer Bhasha dam projects (Awakul and Ogunlana, 2002; Nüsser and Baghel, 2017; Magsi et al., 2017; Nolte, 2020).

The formulation of the project must also evaluate the geographical proximity among different stakeholders which is the main component in land conflict generation in different ways, including superposition of interests, contiguity, and close neighborhood. After that to mobilize the organized proximity particularly the logic of belonging (Magsi and Torre, 2014). The participation of local people is necessary, especially the involvement of the poorest and day to day users of land and natural resources (fishermen, farmers, and herders) in the decision-making process based on their desires and expectations. Then a better and successful territorial governance could result in a network of directly and indirectly affected people, which could lead to socioeconomic and territorial development by activating the organized proximity.

We also recognize the necessity of a governing body for natural resources protection, which could give different forms of mediation among socioeconomic purposes. As it is the duty of the government authorities to manage and enhance the protection of livelihood as well as biodiversity by taking on board the local communities and stakeholders, a neutral party would carry out this task in a better way not only from the start of the project but also on later stages.

Proximities of both types during this process should be mobilized. Assessment of wanted and unwanted proximities is necessary to differentiate the protectable and exploitable resources whether they are forests, lakes or rich soils, or polluted areas and unfertile grounds respectively according to the desires of local people. After that, the leading governing bodies should enhance the organized proximity among various stakeholders from within the community to build combined projects and future goals.

\subsection{Technical tools and devices}

A big project like dams brings major changes in land use, making a selection of geographic location is the main element in the construction process of big infrastructural projects. It needs careful planning during the selection of the location of the project by taking care of socioeconomic and environmental criteria to avoid conflicts. In this regard territorial analysis, benchmarking procedures, interviews, and group meetings are required. We also recommend the need to reduce asymmetry of power and guarantee attainable employment opportunities. Such ground level rules are necessary for the setting of good governance processes at the territorial level and safeguard the least possible requirements of the local population (Torre and Traversac, 2011).

The importance of developing technical solutions to the problems faced by the implementation of major infrastructure projects, particularly in the phases of discussion with the population, must also be emphasized. Thus, the existence of semi-desired infrastructures (Torre et al., 2015) refers to situations in which it is both necessary to find a solution to economic problems but also to respond to the objections raised by these projects. In order to remove reservations and objections, it is also necessary to find technical solutions. For example, in the case of dams, to ensure the quality of the resettlement, to guarantee the availability of land in other locations or to move remarkable sites for example. At this price, large-scale projects become more acceptable by populations who also perceive their interest in economic and welfare terms. 


\section{Conclusion}

Infrastructural conflicts take an increasing place in many developing countries like Pakistan, related to the setting of big infrastructures devoted to the requirements and welfare of the local populations, but sometimes in contradiction with their concrete wills. In this paper, two cases of infrastructure development (Chotiari and Diamer Bhasha Dams) from Pakistan were studied in terms of superposition and oppositions of land use expectations with their several elements of conflict among various actors over territory and resources.

The qualitative data collected from both primary and secondary sources show that the conflicts are mainly linked to the construction of the projects and various economic, social, and environmental issues. Both projects have hampered socioeconomics and damaged natural resources, where such management practices are being implemented in Pakistan for a long. The livelihood of local populations was affected by mismanagement, corruption, and favoritism of payment of the compensation. It is concluded that the difference of opinion of the local population with the public and private body in the process of decision making created several conflicts among different stakeholders from the local level to the national level.

Therefore, it was observed a lack of meaningful territorial governance, which would have played a vital part in forecasting and/or alleviating land use conflicts. This seems like a trend in the decision-making process of many developing countries; however, we do claim that the situation would be otherwise radically different if various proximities i.e., geographical, and organized, are mobilized. Settling the conflicting relationships among different stakeholders related to the project is a great challenge in Pakistan, but this matter needs a lot of debate in other parts of the developing world as well. Strong governance is also linked to strong negotiations among main stakeholders, which requires capacity building so that a sustainable and balanced natural resource use and ecosystem must be managed. It is also linked with the capabilities and the empowerment of the local population to ensure their effective participation. Thus, results of our cases studies suggested comprehensive devices for developing policy recommendations to avoid conflicts which can, in the same way, be applied to other cases of the global south.

\section{Acknowledgements}

The authors would like to acknowledge the support from Pakistan Water and Power Development Authority (WAPDA) and Sindh Irrigation and Drainage Authority (SIDA) for dissemination of required information for this study, and Dr. Salman. Atif for case study maps. The authors also thank to the anonymous reviewers for their constructive suggestions on earlier version of the article.

\section{References}

Abro, A.A. (2001). Chotiari Reservoir: Resettlement Action Plan. In: DevFound (ed.) At Odds or At Ease? NGOs and Local Communities in World Bank Supported Projects in Pakistan. Islamabad. 66-86.

Ali, Z. \& Nasir, A. (2010). Land Administration System in Pakistan: Current Situation and Stakeholders' Perception. April 11-16, 2019. Retrieved from 
[http://www.fig.net/resources/proceedings/fig_proceedings/fig2010/papers/fs03f/fs03f_al i_nasir_3901.pdf]

Almeidaa, J., Costab, C. \& Silvaa, F.N. (2017). A framework for conflict analysis in spatial planning for tourism. Tourism Management Perspectives, 24, 94-106.

Awakul, P. \& Ogunlana, S.O. (2002). The effect of attitudinal differences on interface conflict on large construction projects: The case of the Pak Mun Dam project. Environmental Impact Assessment Review, 22:4, 311-335.

Baghel, R. \& Nüsser, M. (2010): Discussing large dams in asia after the World Commission on Dams: Is a political ecology approach the way forward? Water Alternatives, 3(2), 231248.

Campbell, D. J., Gichohi, H., Mwangi, A. \& Chege, L. (2000). Land use conflict in Kajiado District, Kenya. Land Use Policy, 17, 337-348.

Cheshire, P. \& Vermeulen, W. (2009). Land Markets and their Regulation: The Welfare Economics of Planning. In Geyer, H.S. (Eds.) International handbook of urban policy, vol. II: Issues in the developed world. Cheltenham, UK : Edward Elgar. Pp. 152-193.

Dawn, (2006). All reservoirs will be built: Musharraf: Diamer-Bhasha dam project launched. Dawn News, April 27. Retrieved from [http://www.dawn.com/news/189653/allreservoirs-will-be-built-musharraf-diamer-bhasha-dam-project-launched]

Deininger, K. \& Castagnini, R. (2006). Incidence and impact of land conflict in Uganda. Journal of Economic Behavior \& Organization, 60(3), 321-345.

GoP. (1993). Resettlement Plan and Environmental Impact Assessment for Chotiari Reservoir and Nara Remodeling. LBOD Stage 1 project. Water and Power Development Authority, December.

GoP. (1998). Environmental Management and Monitoring plan. LBOD Stage 1 project. Water and Power Development Authority, April.

GoP. (2013). WAPDA Annual Report 2012-13. Water and Power Development Authority Pakistan. Retrieved

From:

[http://www.wapda.gov.pk/images/phocadownloadapp/AnnualReports/annualreport_201 2_13.pdf].

GoP. (2020). Pakistan Economic Survey 2019-20. Ministry of Finance, Revenue and Economic Affairs, Islamabad. June 2020.

Ha, K.M., Hung, P.G., Magsi, H., Hieu, N.N. \& Hao, O.M. (2016). Evaluating and Orienting the Agricultural Land use Systems to Serve the Land use Planning Progress in Viet-Yen District, Bac-Giang Province, Vietnam. Indian Journal of Science and Technology, 9(18), $1-7$.

Hirschman, A.O. (1970). Exit, Voice, and Loyalty: Responses to Decline in Firms, Organizations, and States. Cambridge, MA: Harvard University Press.

Iqbal, N. (2004). Affectees of Tarbela and Chotiari Dams: A struggle for social justice. United Nations Environmental Program. Addressing Existing Dams, Issue based workshop, 1415 June. 69-72.

Magsi, H. \& Torre, A. (2014). Proximity analysis of inefficient practices and socio-spatial negligence: Evidence, evaluations and recommendations drawn from the construction of Chotiari reservoir in Pakistan, Land Use Policy, 36, 567-576. 
Magsi, H., Torre, A., Liu, Y. \& Sheikh, M.J. (2017). Land use Conflicts in the developing countries: Proximate driving forces and preventive measures. Pakistan Development Review, 56(1), 19-30.

Mahato, B.K. \& Ogunlana, S.O. (2011). Conflict Dynamics in Dam Construction Project: A Case Study. Built Environment Project and Asset Management, 1(2), 176-194.

Mann, C. \& Jeanneaux, P. (2009). Two Approaches for Understanding Land Use Conflicts to Improve Rural Planning and Management. Journal of Rural and Community Development, 4 (1),118-141.

McCarthy, J.D., McPhail, C. \& Smith, J. (1996). Images of protest: dimensions of selection bias in media coverage of Washington demonstrations, 1982-1991. American Sociological Review, 61(3), 478-499.

Mirani, Z., Kumbhar, M.I., Magsi, H. \& Mughal, S. (2014). Rural Women role in agriculture of Pakistan: contributions and constraints. Journal of Business Strategies, 8(2), 83-96.

Nauman, M. (2003). Ravaged Ecology, Cruel Displacement and Impoverished Livelihoods. Water Nepal, $9(1 / 2), 313-318$.

Nolte, K. (2020). Doomed to fail? Why some land-based investment projects fail. Applied Geography, 122, 1-17.

Nüsser, M. \& Baghel, R. (2017): The emergence of technological hydroscapes in the Anthropocene: Socio-hydrology and development paradigms of large dams. In: Warf B (ed.): Handbook on geographies of technology. Cheltenham: Edward Elgar (Research Handbooks in Geography Series), 287-301.

Nüsser, M. (2003): Political ecology of large dams: A critical review, Petermanns Geographische Mitteilungen, 147(1), 20-27.

Ostrom, E. \& Nagendra, H. (2006). Insights on Linking Forests, Trees, and People from theAir, on the Ground, and in the Laboratory. Proceedings of the National Academy of Sciences, 103(51), 19224-19231.

Ostrom, E. (1990). Governing the Commons: The Evolution of Institutions for Collective Action. Cambridge University Press, Cambridge.

Sabir, M., Torre, A. \& Magsi, H. (2017). Land-use conflict and socio-economic impacts of infrastructure projects: the case of DiamerBhasha Dam in Pakistan. Area Development and Policy, 2(1), 1-15.

Scudder, T. 2005. The Future of Large Dams: Dealing with Social, Environmental, Institutional and Political Costs. Earthscan, London.

Sen, A. (1999). Development as Freedom. Oxford University Press, USA.

Tilt, B., Braun, Y. \& He, D. (2009). Social impacts of large dam projects: A comparison of international case studies and implications for best practice. Journal of Environmental Management. 90, S249-S257.

Torre, A. \& Traversac, J.B. (2011). Territorial Governance: Local Development, Rural Areas and Agrofood Systems. Springer. New York USA.

Torre, A., Melot, R., Magsi, H., Bossuet, L., Cadoret, A., Caron, A., Darly, S., Jeanneaux, P., Kirat, T., Pham H.V. \& Kolokouris, O. (2014). Identifying and measuring land-use and proximity conflicts: methods and identification. SpringerPlus, 3, No. 85.

Torre, A., Pham, H.V. \& Simon, A. (2015). The ex-ante impact of conflict over infrastructure settings on residential property values in Paris's suburban zones. Urban Studies, 52(13), 2404-2424. 
Wehrmann, B. (2008). Land conflicts: A practical guide to dealing with land disputes. Handbook, Deutsche Gesellschaft für Technische Zusammenarbeit (GTZ), Eschborn, Germany. 